\title{
Differential Effect of Follicle-Stimulating Hormone and Estradiol on Expressions of Vascular Endothelial Growth Factor (VEGF) 120, VEGF164 and Their Receptors in Bovine Granulosa Cells
}

\author{
Takashi SHIMIZU1), Barana C. JAYAWARDANA ${ }^{1)}$, Masafumi TETSUKA ${ }^{2)}$ and \\ Akio MIYAMOTO ${ }^{1}$
}

${ }^{1)}$ Graduate School of Animal and Food Hygiene, ${ }^{2)}$ Department of Agriculture and Life Science, Obihiro University of Agriculture and Veterinary Medicine, Inada-machi, Obihiro, Hokkaido 080-8555, Japan

\begin{abstract}
Vascular endothelial growth factor (VEGF) isoforms (VEGF 120 and VEGF 164) secreted by granulosa cells are involved in thecal angiogenesis during follicular development in the bovine ovary. However, whether the transcript of the VEGF120 and VEGF164 isoforms differs during follicular development in the ovary is still unknown. We first examined the gene expression of VEGF120, VEGF164, fms-like tyrosine kinase (Flt-1), and fetal liver kinase (Flk-1) in the granulosa cells (GCs) and theca cells (TCs) of pre-selection and post-selection follicles (PRF and POF respectively) from the bovine ovary. Then we examined the effects of FSH and estradiol (E2) on these factors in cultured bovine GCs. Messenger RNA (mRNA) expression was quantified using real-time PCR methods. The concentrations of E2 and P4 in the follicular fluid (FF) of the PRF and POF were estimated using an enzyme immunoassay (EIA). The concentrations of E2 and P4 in the FF were significantly higher in the POF than in the PRF. The ratio of E2/P4 in PRF and POF was 0.37 and 3.8, respectively. The expression levels of the VEGF120, VEGF164, and Flk-1 mRNAs in the GCs of POF with high E2 concentration were higher than those of PRF. The levels of the Flt-1 and Flk-1 mRNAs in the TCs were not different between PRF and POF. Since E2 in the FF of the POF used in the present study was high compared with the PRF, we examined the effects of E2 and FSH on the expression of the above genes using cultured GCs. Expression of VEGF120 mRNA was induced by a low concentration $(1 \mathrm{ng} / \mathrm{ml}) \mathrm{of}$ E2, whereas the levels of VEGF164 and Flk-1 mRNAs were not affected by E2. FSH stimulated the expression of the VEGF isoforms and Flk-1 genes. Moreover, the expression of those genes was enhanced when low E2 $(1 \mathrm{ng} / \mathrm{ml})$ was added to FSH. In conclusion, our data indicates that the VEGF isoforms have a follicle stage-dependent expression pattern. Thus, our results suggest that the expression of VEGF isoforms may be associated with characterization of the preovulatory phenotype during follicle development in the bovine ovary.

Key words: Estradiol, Fetal liver kinase (Flk-1), Fms-like tyrosine kinase (Flt-1), Follicle-stimulating hormone (FSH), Granulosa cell, Vascular Endothelial Growth factor (VEGF)
\end{abstract}

(J. Reprod. Dev. 53: 105-112, 2007)

Accepted for publication: September 19, 2006

Published online: October 14, 2006

Correspondence: T. Shimizu (e-mail: shimizut@obihiro.ac.jp) ascular endothelial growth factor (VEGF) was originally isolated based on its ability to specifically stimulate microvascular endothelial cells to proliferate [1-4]. VEGF mRNA was first 
detected in the thecal and granulosa cell layers of late secondary follicles [5]. An increase in VEGF mRNA expression is observed within the granulosa cells of follicles in the tertiary stage, whereas in atretic follicles, VEGF expression is reduced in the granulosa cells and is no longer detectable in the theca cells [5]. Five molecular forms of VEGF are produced as a result of alternative splicing; three of them (VEGF120, VEGF 145, and VEGF 165) are soluble isforms, and the other two larger forms (VEGF 188 and VEGF 205) are generally membrane bound [6]. VEGF 120 and VEGF 164 are expressed in the mammalian ovary $[7,8]$ and are associated with follicular angiogenesis during follicular development $[9,10]$. In vivo injection of VEGF gene or protein induces the emergence of a large number of preovulatory and antral follicles [11-13]. These reports indicate that VEGF is a crucial factor during follicular development in the ovary.

VEGF acts via two tyrosine kinase-family receptors, namely fms-like tyrosine kinase (Flt-1) and fetal liver kinase (Flk-1) [14]. The mRNA for the Flt- 1 and Flk-1 receptors, which is localized in the endothelial cells of the theca of late secondary follicles, increases in the theca of tertiary follicles and decrease in atretic follicles [5]. Our previous study showed that the expression of the Flt-1 gene increased more than the expression of the Flk-1 gene in the theca cells when VEGF was overexpressed in the granulosa cells by direct ovarian injection of its gene fragment [11]. In addition, a study using the equine chorionic gonadotropin (eCG)-treated pigs indicated that the differences between the control and eCG groups in VEGF 120 gene expression in medium and large follicles were larger than those for VEGF 164 [9]. These results led us to hypothesize that the actions of the VEGF120 and VEGF164 isoforms may differ depending on the stage of follicular development in the ovary.

To test this hypothesis, we first investigated the expression of VEGF120 and VEGF 164 mRNAs in granulosa cells (GCs) and the mRNA levels for their receptors in the GCs and theca cells (TCs) of pre-selection and post-selection follicles collected from the bovine ovary. Then, we further examined the hormonal effects of FSH and estradiol-17 $\beta$ (E2) on the levels of mRNA expression of VEGF120, VEGF164, and their receptors in cultured bovine granulosa cells.

\section{Materials and Methods}

\section{Sample collection}

Paired ovaries were obtained from 21-26-monthold non-parous Holstein x Japanese Black F1 heifers at a local slaughterhouse. Only ovarian pairs with a corpus luteum (CL) and apparently normal follicles were used in the present study. Follicular fluid (FF) was aspirated from selected follicles using a syringe fitted with a $20 \mathrm{G}$ needle and kept at $-20 \mathrm{C}$. The theca cell layer and granulosa cells were harvested from the aspirated follicles. The tissue samples were placed in RNAlater (Ambion, Austin, TX, USA) and frozen at $-30 \mathrm{C}$. Follicles were classified into two groups based on diameter [postselection follicles (POF) were $11.0-19.0 \mathrm{~mm}$ in diameter; pre-selection follicles (PRF) were 7.0-8.5 $\mathrm{mm}$ in diameter].

Bovine granulosa cell culture and hormone treatment

Ovaries were obtained at a slaughterhouse from cows and heifers just after slaughter. After transport to the laboratory at $30 \mathrm{C}$, the ovaries were washed three times with prewarmed McCoy's 5A medium. Granulosa cells were collected from small size follicles (4-7 $\mathrm{mm}$ ) by aspiration using a needle (18 gauge) and syringe (plastic, $10 \mathrm{ml}$ ) and were washed in Dulbecco's Modified Eagle's Medium/ F12 medium (DMEM/F12). The number of viable cells was determined using trypan blue exclusion. Then, the cell suspension was centrifuged, resuspended, and seeded at a density of $5 \times 10^{5}$ viable cells per well (24-well culture plate) in $1 \mathrm{ml}$ of DMEM/F12 containing 10\% fetal calf serum (FCS) and antibiotics. The cells were cultured for $24 \mathrm{~h}$ at $37 \mathrm{C}$ in a $5 \% \mathrm{CO}_{2}$ atmosphere, and then the wells were washed with DMEM/F12 to remove unattached cells and any remaining tissue debris. The medium was replaced with serum-free medium supplemented with E2 (1-100 ng/ml) and FSH (1-10 $\mathrm{ng} / \mathrm{ml})$ at several concentrations, and culture was continued for $6 \mathrm{~h}$. Treatments were terminated by aspirating the medium and rinsing the cells twice with phosphate-buffered saline, and then the cells were used for RNA extraction. All experiments were repeated three times in triplicate.

\section{RNA extraction and reverse transcription (RT)}

Tissue samples were homogenized in denaturing solution containing $4 \mathrm{M}$ guanidium thiocyanate (Wako Pure Chemical, Osaka, Japan), 25 mM 
Table 1. Primer pairs used for detection of mRNAs

\begin{tabular}{clcc}
\hline Target gene & \multicolumn{1}{c}{ Sequence } & \multicolumn{1}{c}{ Size (bp) } & aEMBL/Reference \\
\hline VEGF120 & $\begin{array}{l}\text { Forward: 5'-GCC TCG GCT TGT CAC ATT TT-3' } \\
\text { Reverse: 5'-ACC GCC TCG GCT TGT CAC-3' }\end{array}$ & 254 & [26] \\
VEGF164 & $\begin{array}{l}\text { Forward: 5'- AGC AAG GCC CAC AGG GAT TT-3' } \\
\text { Reverse: 5'-ACC GCC TCG GCT TGT CAC-3' }\end{array}$ & 310 & {$[26]$} \\
Flt-1 & $\begin{array}{l}\text { Forward: 5'-GAA GGA CGG GAT GAG GAT GC-3' } \\
\text { Reverse: 5'-ATG GCG TTG AGC GGA ATG TA-3' }\end{array}$ & 186 & X94263 \\
Flk-1 & $\begin{array}{l}\text { Forward: 5'-TGG CCC AAC AAT CAG AGC AG-3' } \\
\text { Reverse: 5'-GAA CGG AGC CCA TGT CAG TG-3' }\end{array}$ & 154 & X94298 \\
& $\begin{array}{l}\text { Forward: 5'-CCA AGG CCA ACC GTG AGA AGA T -3' } \\
\text { Reverse: 5'-CCA CGT TCC GTG AGG ATC TTC A-3' }\end{array}$ & 256 & K00622 \\
\hline
\end{tabular}

a: EMBL accession number or reference for the published sequence.

sodium citrate, $0.5 \%$ sarkosyl (Sigma Chemical, St. Louis, MO, USA), and 0.1M $\beta$-mercaptoethanol (Kanto Chemical, Tokyo, Japan). Total RNA was extracted with phenol chloroform, further purified and treated with DNase using a commercial kit (SV total RNA Isolation System; Promega, Madison, WI, USA), and frozen at -20 C in THE RNA Storage Solution (Ambion). Single-stranded cDNA was reverse transcribed from total RNA $(0.5-1.0 \mu \mathrm{g})$ using a 1st Strand cDNA Synthesis Kit for RT-PCR (Roche Diagnostics, Indianapolis, IN, USA) and a random primer. Each RT cycle consisted of $10 \mathrm{~min}$ of annealing at $25 \mathrm{C}, 60 \mathrm{~min}$ of cDNA synthesis at $42 \mathrm{C}$, and $5 \mathrm{~min}$ of inactivation at $99 \mathrm{C}$.

\section{Quantitative real-time PCR}

Transcripts for VEGF120, VEGF164, Flt-1, Flk-1, and $\beta$-actin were quantified by real-time PCR with a LightCycler (Roche Diagnostics) using a commercial kit (QuantiTect ${ }^{\text {TM }}$ SYBR ${ }^{\circledR}$ Green PCR; Qiagen, Hilden, Germany). The primers were designed using Primer-3 based on the bovine sequences (Table 1). The Primers for VEGF 120 and VEGF 164 were designed by Wellmann et al. [26]. The amplification program consisted of an initial 15-min activation at $95 \mathrm{C}$ followed by 40 cycles of PCR (each cycle consisting of $15 \mathrm{sec}$ of denaturation at $94 \mathrm{C}, 30 \mathrm{sec}$ of annealing at $58 \mathrm{C}$ and $20 \mathrm{sec}$ extension at $72 \mathrm{C}$ ). For quantification of the target genes, a series of standards were constructed by amplifying a fragment of DNA (to $700 \mathrm{bp}$ ) that contained the target sequence for real-time PCR $(100-150 \mathrm{bp})$. The PCR products were subjected to electrophoresis, and the target band was cut out and purified using a DNA purification kit (SUPREC $^{\text {TM}}-01$, TaKaRa Bio, Ohtsu, Japan). Three to five serially diluted DNA standards were included in every PCR run. The values were normalized using $\beta$-actin as the internal standard.

\section{Steroid hormone assay}

Concentrations of E2 and progesterone (P4) in the FF samples were estimated by an enzyme immunoassay (EIA) as described previously [15, 16]. Steroid hormones were extracted with diethyl ether. The extraction efficiency was $85 \%$. The ranges of the standard curves were $2-2,000 \mathrm{pg} / \mathrm{ml}$ for E2 and $0.05-50 \mathrm{ng} / \mathrm{ml}$ for P4. The intra- and interassay coefficients of variation were 6.2 and $8.5 \%$ for E2 and 4.5 and $7.4 \%$ for P4.

\section{Data analysis}

All data are presented as means \pm SEM. The differences in expression of VEGF120, VEGF164, Flk-1, and Flt-1 and in the concentrations of estradiol and progesterone in follicular fluid between POF and PRF were analyzed by Student's $t$-test. Data for several factors in relation to the treated bovine granulosa cells were tested for the significance of differences using ANOVA followed by the Fisher's LSD test as a multiple comparison test. Differences were considered significant at $\mathrm{P}<0.05$ or less.

\section{Results}

\section{Characteristics of follicles}

Table 2 shows the conditions of the ovarian follicles used in this study. The concentrations of estradiol and progesterone in the follicular fluid increased significantly in the post-selection follicles 
Table 2. Mean follicle diameter, concentrations of estradiol $(\mathrm{E})$ and progesterone $(\mathrm{P})$ in the follicular fluid, and $\mathrm{E} / \mathrm{P}$ ratio in the cattle

\begin{tabular}{ccccc}
\hline & & \multicolumn{2}{c}{ Follicular fluid } & \\
\cline { 3 - 3 } Follicle & Mean follicle diameter $(\mathrm{mm})$ & Estradiol $(\mathrm{ng} / \mathrm{ml})$ & Progesterone $(\mathrm{ng} / \mathrm{ml})$ & E/P ratio \\
\hline Pre-selection follicles $(\mathrm{n}=7)$ & $7.8 \pm 0.2$ & $3.14 \pm 1.0^{*}$ & $13.2 \pm 3.0^{*}$ & $0.37 \pm 0.1^{*}$ \\
Post-selection follicles $(\mathrm{n}=7)$ & $15.3 \pm 1.2$ & $81.8 \pm 14.5$ & $21.8 \pm 2.1$ & $3.8 \pm 0.6$ \\
\hline
\end{tabular}

Values are means \pm SEM. *: $\mathrm{P}<0.05$ versus post-selection follicles.

A

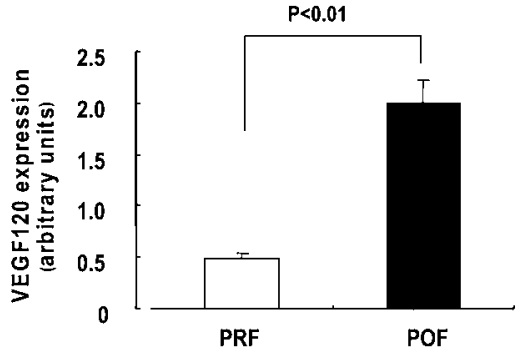

B

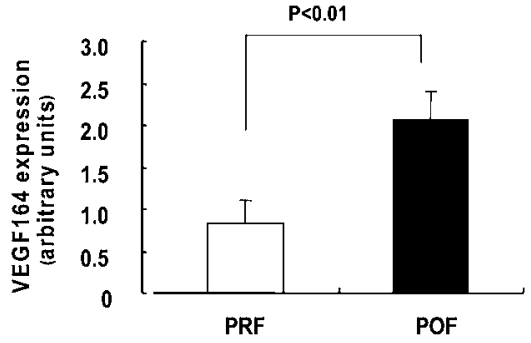

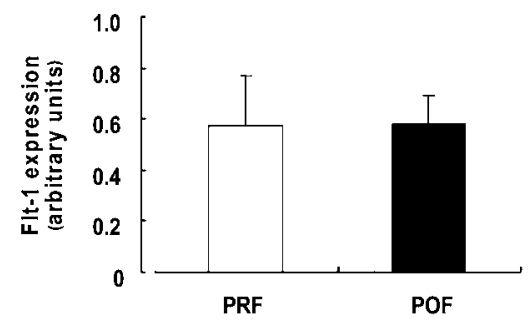

D

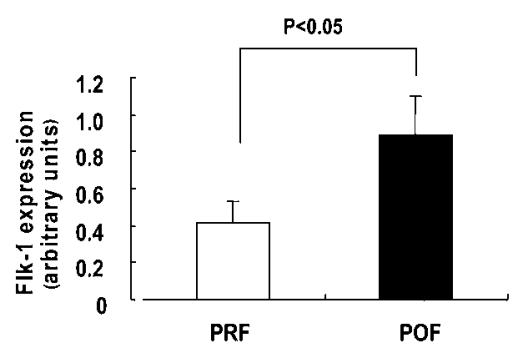

Fig. 1. Expression of VEGF120 (A), VEGF164 (B), Flt-1 (C) and Flk-1 (D) mRNAs in the granulosa cells of pre-selection (PRF, $n=7)$ and post-selection (POF, $n=7)$ follicles. The data are expressed as means \pm SEM. The expression of each factor was normalized on the basis of $\beta$-actin expression.

(POF) compared to the pre-selection follicles (PRF). The ratio of E2/P4 in the POF and PRF were $3.8 \pm$ 0.6 and $0.37 \pm 0.1$, respectively.

Messenger RNA expression of VEGF120, VEGF164, and related receptors in the granulosa and theca cells of the POF and PRF

The expression of VEGF120 and VEGF164 mRNAs in the GCs of the POF with a high E2 concentration was higher than in those of the PRF (Figs. 1A and B). On the other hand, for receptors, the levels of Flk-1 mRNA increased significantly in the GCs of the POF compared to those of the PRF, while the level of Flt-1 mRNA was the same in the POF and PRF (Figs. 1C and D). The levels of Flt-1 and Flk-1 mRNAs in the TCs did not differ between the POF and PRF (Figs. 2A and B).

Effect of estradiol on the expression of VEGF120, VEGF164, and Flk-1 mRNAs in cultured granulosa cells

Expression of VEGF120 mRNA was induced in the cultured GCs with a low concentration (1 ng/ $\mathrm{ml}$ ) of E2 (Fig. 3A). In contrast, the levels of VEGF164 and Flk-1 mRNA were not affected by E2 (Figs. 3B and C).

Effect of FSH on the expression of VEGF120, VEGF164, and Flk-1 mRNAs in cultured granulosa cells

Expression of VEGF120 mRNA in the cultured GCs increased when $10 \mathrm{ng} / \mathrm{ml} \mathrm{FSH}$ was added to 


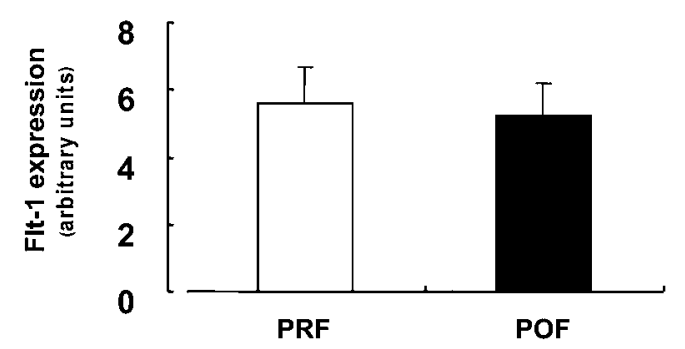

B

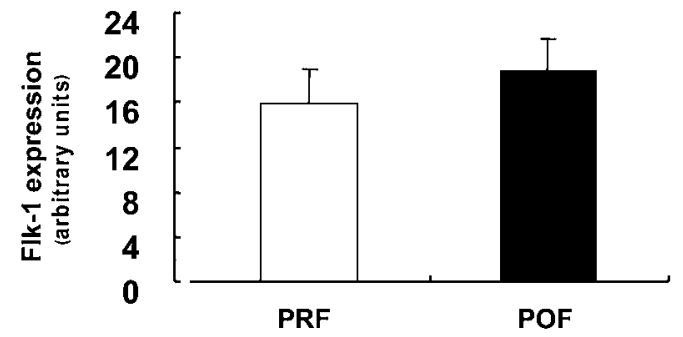

Fig. 2. Expression of Flt-1 (A) and Flk-1 (B) in the theca cells of pre-selection (PRF, $\mathrm{n}=7$ ) and postselection (POF, $n=7$ ) follicles. The data are expressed as means \pm SEM. The expression of each factor was normalized on the basis of betaactin expression.

the culture medium (Fig. 4A). Addition of $1 \mathrm{ng} / \mathrm{ml}$ FSH significantly increased VEGF164 mRNA expression compared with the other concentrations tested (Fig. 4B). Expression of the Flk-1 gene was significantly increased by 1 to $10 \mathrm{ng} / \mathrm{ml} \mathrm{FSH}$ (Fig. $4 C)$.

Effect of E2 plus FSH on the expression of VEGF120, VEGF164, and Flk-1 mRNAs in cultured granulosa cells

The combination of $1 \mathrm{ng} / \mathrm{ml} \mathrm{E} 2$ and $1 \mathrm{ng} / \mathrm{ml} \mathrm{FSH}$ stimulated expression of the VEGF120, VEGF164, and Flk-1 genes (Fig. 5 A-C). At a constant concentration of $1 \mathrm{ng} / \mathrm{ml} \mathrm{E} 2$, the expression of the VEGF120 and Flk-1 genes was more markedly stimulated by $5 \mathrm{ng} / \mathrm{ml} \mathrm{FSH}$ than $1 \mathrm{ng} / \mathrm{ml} \mathrm{FSH}$ (Fig. $5 \mathrm{~A}$ and $\mathrm{C})$. In contrast, the expression of the VEGF164 gene did not change as the FSH concentration was increased (Fig. 5B).
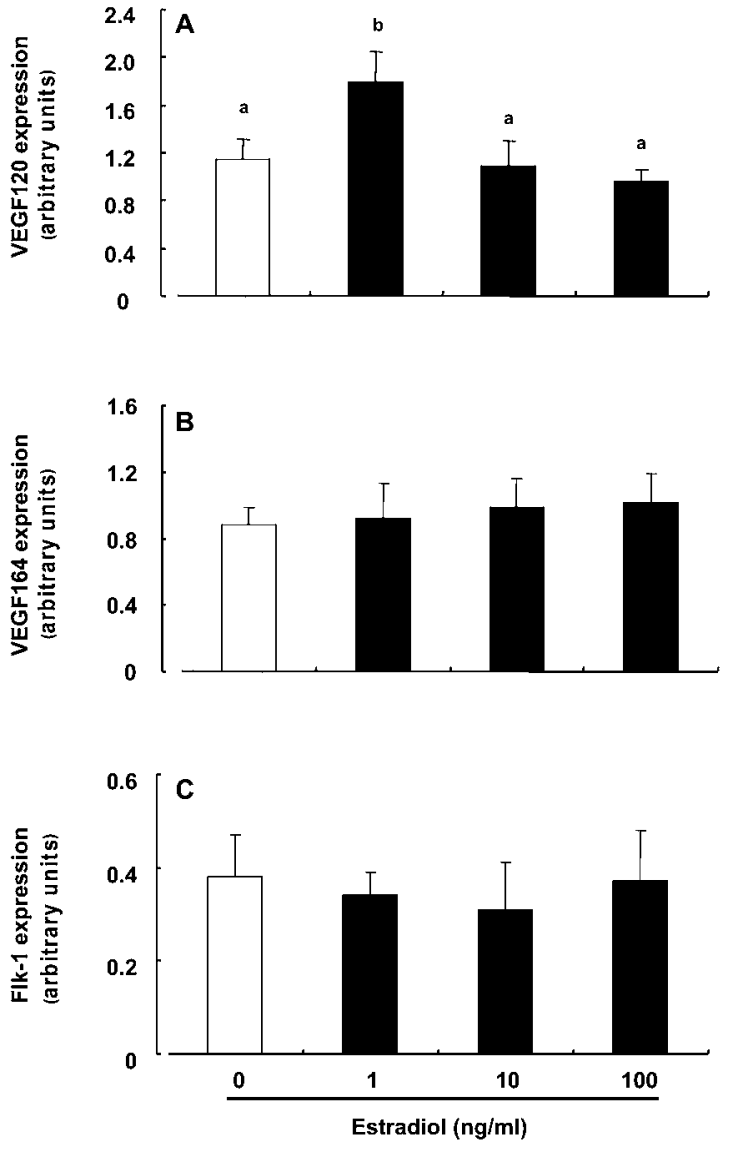

Fig. 3. Effect of estradiol on the expression of VEGF120 (A), VEGF164 (B), and Flk-1 (C) mRNAs in cultured bovine granulosa cells. E2 was added to the culture medium at each indicated concentration. The data are expressed as means \pm SEM of three separate experiments with triplicate determinations in each. Different superscripts denote significantly different values $(\mathrm{P}<0.05)$.

\section{Discussion}

The results of the present study indicate that expression of the VEGF120, VEGF 164, and Flk-1 genes increased in the GCs of the post-selection follicles, which possess high E2 levels compared with those of the pre-selection follicles, and that these factors were upregulated by E2 and FSH in the cultured GCs. We found that the expression level of Flt-1 gene in the GCs remained constant across the periods of follicle selection, whereas Flk1 expression in the GCs increased from the preselection to post-selection period. A recent study 

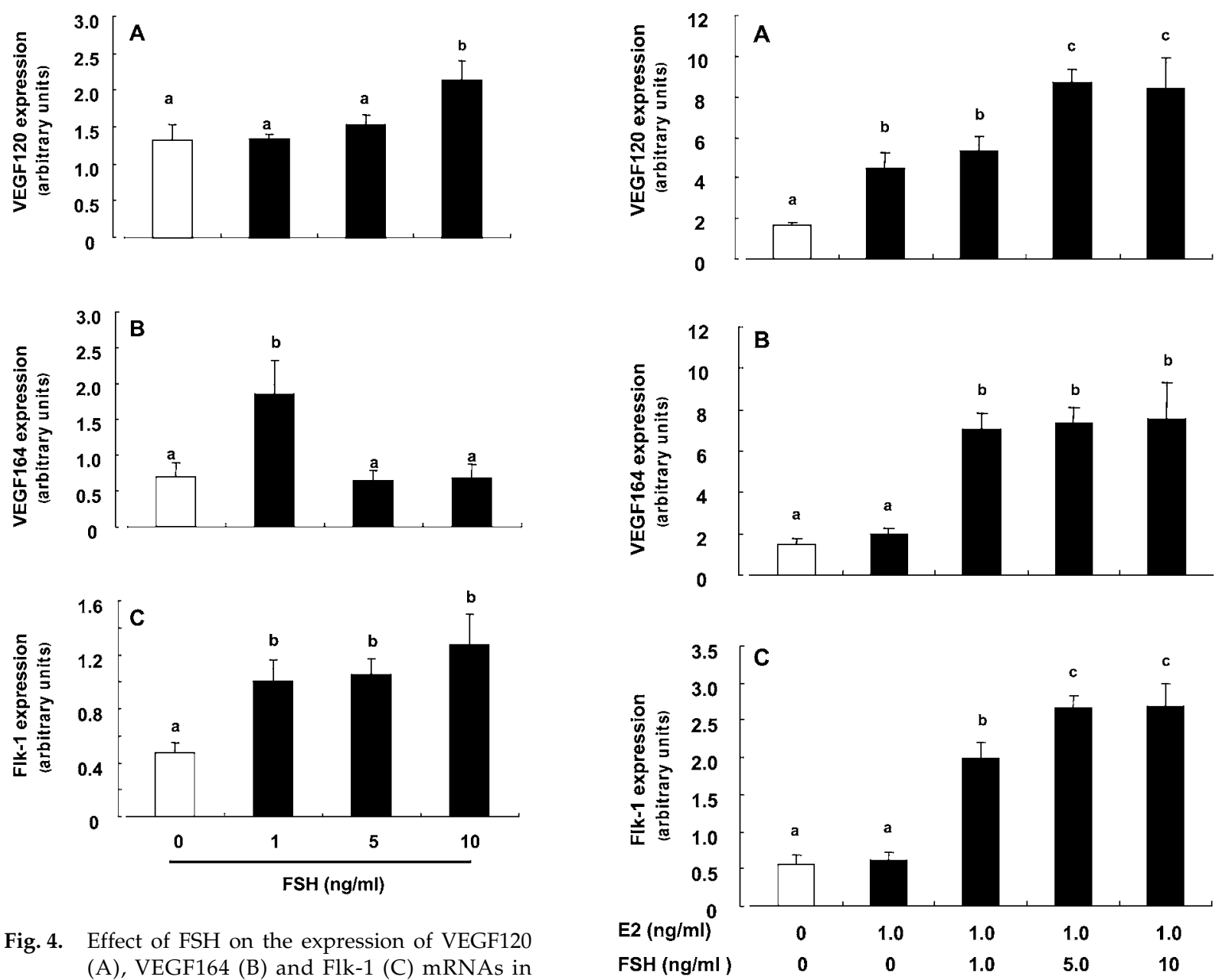

Fig. 4. Effect of FSH on the expression of VEGF120 (A), VEGF164 (B) and Flk-1 (C) mRNAs in cultured bovine granulosa cells. Each indicated concentration of E2 was added to the culture medium. The data are expressed as means \pm SEM of three separate experiments with triplicate determinations in each experiment. Different superscripts denote significantly different values $(\mathrm{P}<0.05)$.

demonstrated that VEGF inhibited apoptosis in GCs via Flk-1 [17]. Therefore, we speculate that Flk-1 is essential for transducing the biological actions of VEGF in bovine GCs. On the other hand, expression of the Flt-1 and Flk-1 genes in TCs did not change developing on the period of follicle selection in the present study, which is similar to the findings of a previous study [8]. These results show that pre-selection follicles already sufficiently express the genes for both receptors in the TCs. In contrast, in the porcine ovary, the expression of Flk$1 / \mathrm{KDR}$ mRNA increases in the thecal tissue of medium and large follicles after eCG treatment in parallel with the expression of VEGF 120 and VEGF

Fig. 5. Effect of E2 and FSH on the expression of VEGF120 (A), VEGF164 (B), and Flk-1 (C) mRNAs in cultured bovine granulosa cells. Each indicated concentration of estradiol was added to the culture medium. The data are expressed as means \pm SEM of three separate experiments with triplicate determinations in each. Different superscripts denote significantly different values $(\mathrm{P}<0.05)$.

164 mRNAs [9]. This difference may be related to the difference in the form of follicular growth (mono- versus multiovular).

The follicular fluid of dominant follicles contains higher amount of E2 than that of subordinate follicles in the bovine ovary $[18,19]$. In fact, our results indicate that the concentrations of $\mathrm{E} 2$ and $\mathrm{P} 4$ in the follicular fluid of the post-selection follicles $(\mathrm{E} 2 / \mathrm{P} 4>1)$ were higher than those of the preselection follicles $(\mathrm{E} 2 / \mathrm{P} 4<1)$. Our data also indicated that E2 stimulates the expression of the 
VEGF120 but not the VEGF164 gene in bovine GCs. These results suggest that the expression of VEGF genes induced by E2 may differ among isoforms in the GCs during follicle development in the bovine ovary. Estrogens increase the expression of VEGF mRNA by binding to the specific estrogen response elements in the VEGF gene [20] and have been shown to rapidly upregulate VEGF mRNA expression in the mouse [21], rat [22, 23], and sheep [24] uterus and in cultured bovine GCs [25]. Therefore, our data suggests that the transcription of VEGF 120 but not VEGF 164 genes may be induced via estrogen receptors.

VEGF 120 and VEGF 164 expression increases in the GCs of follicles from the eCG-treated porcine ovary [9]. Our results demonstrate that FSH stimulates the expression of the VEGF120, VEGF164, and Flk-1 genes in bovine GCs. Interestingly, expression of the VEGF164 gene was stimulated at low concentration of FSH $(1 \mathrm{ng} / \mathrm{ml})$, whereas VEGF 120 expression was induced by a high FSH concentration $(10 \mathrm{ng} / \mathrm{ml})$. This result suggests that FSH may influence the abundance of VEGF isoform transcript in bovine GCs. However, it is still unknown how FSH induces the different expression patterns of VEGF isoforms.

In the present study, the expression levels of the VEGF120, VEGF164, and Flk-1 genes in the GCs increased at low estradiol concentration $(1 \mathrm{ng} / \mathrm{ml})$ when FSH was also added. These results suggest that a basal level of estradiol enhances the effect of $\mathrm{FSH}$ on the expression of these genes. Further studies in vivo are necessary to confirm whether the preovulatory follicle in the cow shows enhanced expression of VEGF isoforms and their receptors.

In conclusion, our data demonstrates that estradiol and FSH stimulated the expression of the VEGF120 and VEGF 164 genes, and that Flk-1 expression is FSH-dependent, suggesting a follicle stage-dependent expression pattern for VEGF isoforms. Thus, our study suggests that the expression of VEGF isoforms may be associated with the characterization of the dominant follicle (preovulatory phenotype) during follicle development in the bovine ovary. Furthermore, our results strongly suggest that the transcription system for VEGF isoform genes may have different pathways by hormonal stimulation in bovine granulosa cells.

\section{Acknowledgements}

The authors thank Dr. K. Okuda (Okayama University, Japan) for the anti-progesterone antibody. This study was supported by the $21^{\text {st }}$ Century COE program (A-1) of the Ministry of Education, Culture, Sports, Science and Technology, Japan, a Grant-in-Aid for Scientific Research from the Japan Society for the Promotion of Science, the Akiyama Foundation, and the Sumitomo Foundation of Japan.

\section{References}

1. Ferrara N, Davis-Smyth T. The biology of vascular endothelial growth factor. Endocr Rev 1997; 18: 4-25.

2. Stacker SA, Achen MG. The vascular endothelial growth factor family: signaling for vascular development. Growth Factors 1999; 17: 1-11.

3. Connolly DT. Vascular permeability factor: a unique regulator of blood vessel function. J Cell Biochem 1991; 47: 219-223.

4. Senger DR, Van de Water L, Brown LF, Nagy JA, Yeo KT, Yeo TK, Berse B, Jackman RW, Dvorak AM, Dvorak HF. Vascular permeability factor (VPF, VEGF) in tumor biology. Cancer Metastasis Rev 1993; 12: 303-317.

5. Wulff C, Wiegand SJ, Saunders PTK, Scobie GA, Fraser HM. Angiogenesis during follicular development and its inhibition by Flt-1-Fc (VEGF
Trapa40) in the primate. Endocrinology 2001; 142: 3244-3254.

6. Ng YS, Krilleke D, Shima DT. VEGF function in vascular pathogenesis. Exp Cell Res 2006; 312: 527537.

7. Miyabayashi K, Shimizu T, Kawauchi C, Sasada H, Sato E. Changes of mRNA expression of vascular endothelial growth factor (VEGF), angiopoietins and their specific receptors during the periovulatory phase in eCG/hCG-primed immature female rats. $J$ Exp Zool part A 2005; 303: 590-597.

8. Berisha B, Schams D, Kosmann M, Amselgruber $\mathbf{W}$, Einspanier R. Expression and localisation of vascular endothelial growth factor and basic fibroblast growth factor during the final growth of bovine ovarian follicles. J Endocrinol 2000; 167: 371- 
382.

9. Shimizu T, Jiang JY, Sasada H, Sato E. Changes of messenger RNA expression of angiogenic factors and related receptors during follicular development in gilts. Biol Reprod 2002; 67: 1846-1852.

10. Shimizu T, Kawahara M, Abe Y, Yokoo M, Sasada $\mathbf{H}$, Sato E. Follicular microvasculature and angiogenic factors in the ovaries of domestic animals. J Reprod Dev 2003; 49: 181-192.

11. Shimizu T, Jiang JY, Iijima K, Miyabayashi K, Ogawa $Y$, Sasada $H$, Sato E. Induction of follicular development by direct single injection of vascular endothelial growth factor gene fragments into the ovary of miniature gilts. Biol Reprod 2003; 69: 13881393.

12. Danforth DR, Arbogast LK, Ghosh S, Dickerman A, Rofagha R, Friedman CI. Vascular endothelial growth factor stimulates preantral follicle growth in the rat ovary. Biol Reprod 2003; 68: 1736-1741.

13. Quintana R, Kopcow L, Sueldo C, Marconi G, Rueda NG, Baranao RI. Direct injection of vascular endothelial growth factor into the ovary of mice promotes follicular development. Fertil Steril 2004; 82: 1101-1105.

14. Shibuya M. Role of VEGF-flt receptor system in normal and tumor angiogenesis. Adv Cancer Res 1995; 67: 281-316.

15. Miyamoto A, Okuda K, Schweigert FJ, Schams D. Effects of basic fibroblast growth factor, transforming growth factor-beta and nerve growth factor on the secretory function of the bovine corpus luteum in vitro. J Endocrinol 1992; 135: 103-114.

16. Wijayagunawardane MP, Miyamoto A, Cerbito WA, Acosta TJ, Takagi M, Sato K. Local distributions of oviductal estradiol, progesterone, prostaglandins, oxytocin and endothelin- 1 in the cyclic cow. Theriogenology 1998; 49: 607-618.

17. Greenaway J, Connor K, Pedersen HG, Coomber BL, Lamarre J, Petrik J. Vascular endothelial growth factor and its receptor, Flk-1/KDR, are cytoprotective in the extravascular compartment of the ovarian follicle. Endocrinology 2004; 145: 28962905.
18. Bodensteiner KJ, Wiltbank MC, Bergfelt DR, Ginther OJ. Alterations in follicular estradiol and gonadotropin receptors during development of bovine antral follicles. Theriogenology 1996; 45: 499512.

19. Ginther OJ, Bergfelt DR, Kulick LJ, Kot K. Pulsatility of systemic FSH and LH concentrations during follicular-wave development in cattle. Theriogenology 1998; 50: 507-519.

20. Hyder SM, Huang JC, Nawaz Z, Boettger-Tong H, Makela S, Chiappetta C, Stancel GM. Regulation of vascular endothelial growth factor expression by estrogens and progestins. Environ Health Perspect 2000; 108: 785-790.

21. Shweiki D, Neufeld G, Itay-Goren G, Kashet E. Pattern of expression of vascular endothelial growth factor (VEGF) and VEGF receptors in mice suggest a role in hormonally regulated angiogenesis. J Clin Invest 1993; 91: 2235-2243.

22. Cullinan-Bove K, Koos R. Vascular endothelial growth factor/vascular permeability factor expression in the rat uterus: rapid stimulation by estrogen correlates with estrogen-induced increases in uterine capillary permeability and growth. Endocrinology 1993; 133: 829-837.

23. Hyder SM, Stancel GM. Regulation of angiogenic growth factors in the female reproductive tract by estrogens and progestins. Mol Endocrinol 1999; 13: 806-811.

24. Reynolds LP, Kirsch JD, Kraft KC, Redmer DA. Time-course of the uterine response to estradiol17 beta in ovariectomized ewes: expression of angiogenic factors. Biol Reprod 1998; 59: 613-620.

25. Garrido C, Saule S, Gospodarowicz D. Transcriptional regulation of vascular endothelial growth factor gene expression in ovarian bovine granulosa cells. Growth Factors 1993; 8: 109-117.

26. Wellmann S, Taube T, Paal K, Graf V, Einsiedel H, Geilen W, Seifert G, Eckert C, Henze G, Seeger K. Specific reverse transcription-PCR quantification of vascular endothelial growth factor (VEGF) splice variants by LightCycler technology. Clin Chem 2001; 47: 654-660. 